\title{
Urinary Bladder Carcinoma: Impact of Smoking, Age and its Clinico-Pathological Spectrum Joshi HN, ${ }^{1}$ Makaju R, ${ }^{2}$ Karmacharya $A,{ }^{1}$ Karmacharya $R M,{ }^{1}$ Shrestha $B,{ }^{1}$ Shrestha $R,{ }^{3}$ de Jong IJ, ${ }^{4}$ Shrestha RKM ${ }^{1}$
}

\author{
${ }^{1}$ Department of Surgery \\ ${ }^{2}$ Department of Pathology \\ ${ }^{3}$ Department of Pharmacology \\ Dhulikhel Hospital-Kathmandu University Hospital \\ Kathmandu University School of Medical Sciences \\ Dhulikhel, Kavre, Nepal \\ ${ }^{4}$ Department of Urology \\ University Medical Centre Groningen \\ University of Groningen, The Netherlands
}

\section{Corresponding Author}

Hem Nath Joshi

Department of Surgery

Dhulikhel Hospital-Kathmandu University Hospital

Kathmandu University School of Medical Sciences Dhulikhel, Kavre, Nepal

E-mail: hemnjoshi@hotmail.com

\section{Citation}

Joshi HN, Makaju R, Karmacharya A, Karmacharya RM, Shrestha B, Shrestha R et.al. Urinary Bladder Carcinoma: Impact of Smoking, Age and its Clinico-Pathological Ppectrum. Kathmandu Univ Med J 2013;44():292-295.

\begin{abstract}
Background

Urinary bladder carcinoma is common urological malignancy. Although epidemiological evidence favors role of occupational exposure to chemical carcinogen as the aetiological factor of bladder carcinoma, many cases arise with no obvious occupational exposure to chemical carcinogen. Tobacco and cigarette smoking is common in both rural and urban areas of Nepal.
\end{abstract}

\section{Objective}

The objective of this study was to determine the impact of smoking and age in urinary bladder carcinoma with related clinicopathological correlations.

\section{Method}

A total of 56 (44 males and 12 females) cases of urinary bladder cancer treated at Dhulikhel Hospital, Kathmandu University Teaching Hospital during time period of January 2004 to December 2013 were included in the study. Data of patients with Urinary bladder cancer were obtained from hospital records and evaluated for age, sex, history of smoking, clinical presentations, cystoscopic findings and histopathological characteristics.

\section{Results}

Out of 56 cases, 51 (91.1\%) of the patients had hematuria. History of smoking was found in 44 patients. Smoking was found much higher in males (88\%) than females (41.66\%). Transitional cell carcinoma (TCC) was the most common histological variety, which was seen in 51 (91.07\%) patients. The significant impact of smoking was found in terms of grade of TCC.

\section{Conclusion}

The incidence of bladder carcinoma is higher in male and TCC is the most common variety of Urinary bladder malignancy. History of smoking correlated with grade.

\section{KEY WORDS}

Bladder cancer, bladder carcinoma, smoking, transitional cell carcinoma

\section{INTRODUCTION}

Urinary bladder cancer is one of the most common urological malignancies occurring worldwide and its incidence is increasing. In United states alone there were 63210 and 70980 new cases of bladder cancers were diagnosed in 2005 and 2009 respectively and estimated 14,330 death was due to bladder cancer in $2009 . .^{1-3}$ It is the second most common cancer of the genito-urinary tract which accounts for seven percent of new cancer cases in men and two percent of new cancer cases in women.
Cigarette smoking is one of the established causes of this malignancy. The causative carcinogen thought to be beta napthylamine and 4-aminobiphenyl which are secreted into urine of smokers. ${ }^{4}$ In general smokers have up to two to four fold increased risk of urinary bladder cancer than non smokers and this risk correlates with number and duration of cigarette smoked. ${ }^{1,4,5}$ It can occur at any age but the incidence increases directly with age and sex. It is three times more common in men than women. ${ }^{1,6}$ As 
far we know no data has been published reporting on the impact of smoking, age and gender of bladder cancer in Nepal. Therefore this study has been carried out to explore the overall knowledge of the impact of smoking habits, age with related clinico-pathological spectrum of this disease on the patients presented at Dhulikhel Hospital, Kathmandu University Hospital, Nepal.

\section{METHODS}

A total of 56 (44 male and 12 female) cases of urinary bladder cancer treated at Dhulikhel Hospital, Kathmandu University Teaching Hospital during time period of January 2004 to December 2013 were included in the study.

Data of patients with Urinary bladder cancer were obtained from hospital records and evaluated for age, sex, history of smoking, clinical presentations, cystoscopic findings, exposure to other possible risk factors for Urinary bladder carcinoma, and histopathological characteristics at the time of presentation.

After initial clinical evaluation routine urine analysis, haematological, biochemical, radiological (+/- IVU) and ultrasonological investigations were performed. On the basis of positive findings suggestive of bladder cancer in history and investigations; all patients underwent cystoscopy followed by transurethral resection of bladder tumour (TURBT). None of the patients have undergone TURBT previously. In all cases complete removal of bladder tumour was performed and specimen was sent for histopathological examination. Complete removal of tumour along with separate removal of muscle layer was done and sent in separate container for histopathological examination in the case of solid muscle invasive tumour. After initial TURBT all patients with superficial papillary growth have got a course of intravesical instillation of $40 \mathrm{mg}$ mitomycin followed by check cystoscopy in every three months in first one year and six monthly for next two years. Two patients with muscle invasive cancer underwent radical cystectomy with urinary diversion creating ureterostomy. However, remaining ten such cases was not operable.

Data were analyzed using SPSS software version 13.0. For nominal variables, chi square test was performed and $p$ value less than 0.05 was considered to be significant.

\section{RESULTS}

Total fifty six (44 male 12 female with $M: F=3.66: 1$ ) patients of urinary bladder cancer were treated. The age of the patient at presentation ranged from 32-89 years (average age of 61 years). Age and sex wise distribution of the bladder cancer is shown in fig 1 . Most of the patients with bladder carcinoma were between 50 and 70 years of the age.

Regarding clinical features of the patients, haematuria was the most common symptom (91.1\%) at the time

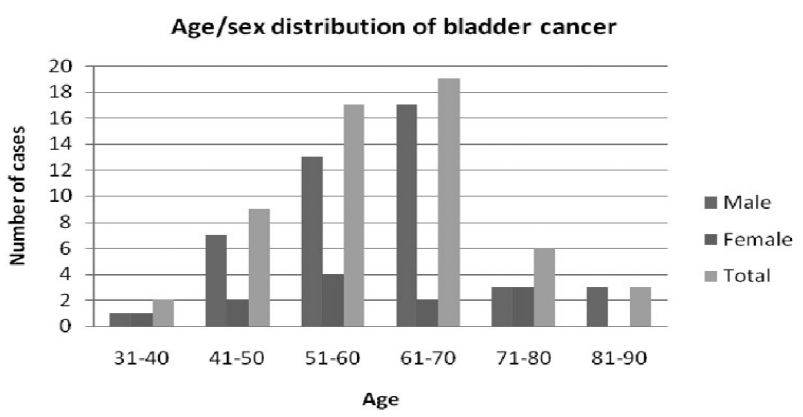

Figure 1. Figure Showing Age and Sex Distribution of Bladder Cancer.

of presentation among which 43 patients were having painless haematuria and 8 patients had painful haematuria followed by irritative lower urinary tract symptoms (LUTS) like acute retention of urine (ARU), dysuria, urgency and increase frequency (Table 1). However, ultrasonography scanning revealed bladder tumour in four patients without any typical clinical symptoms.

Table 1. Clinical Spectrum of Bladder Carcinoma.

\begin{tabular}{|c|c|}
\hline Presentation & Number of patients $=56$ \\
\hline Haematuria & 51 \\
\hline Painless & 43 \\
\hline Painful & 8 \\
\hline \multicolumn{2}{|l|}{ LUTS* } \\
\hline Increase frequency & 22 \\
\hline Urgency & 23 \\
\hline Dysuria & 16 \\
\hline ARU & 6 \\
\hline Incidental USG findings & 4 \\
\hline
\end{tabular}

Among those patients $(\mathrm{N}=56)$ included in this study, the histopathological evaluation revealed papillary transitional cell carcinoma (TCC) in $91 \%$ patients, of which muscle invasive was found to be in 42 patients and non muscle invasive in 9 patients. Similarly, the rest of the cases were of squamous cell carcinoma (SCC; 7\%) and leiomyosarcoma (2\%) patients (Table 2).

Table 2. Histopathological Spectrum of Bladder Cancer.

\begin{tabular}{|lc|}
\hline \multicolumn{1}{|c}{ Presentation } & Number (\%) \\
\hline Transitional cell carcinoma & $51(91)$ \\
\hline Low grade & $16(28.57)$ \\
\hline High grade & $35(62.50)$ \\
\hline Non muscle invasive & $39(69.64)$ \\
\hline Muscle invasive & $12(21.42)$ \\
\hline Squamous cell carcinoma & $04(7.14)$ \\
\hline Leiomyosarcoma & $01(1.78)$ \\
\hline
\end{tabular}

Analysing the smoking habit of those patients, out of 56 patients, $78.6 \%$ patients were found to be a smoker of which $88.6 \%$ was found to be male. The smoker to nonsmoker ratio is found to be 3.66: 1 . Further, 31 out of 35 high grade TCC were smoker and 4 were non smoker. In 
low grade TCC, 7 out of 16 patients were non smoker and 9 were smoker. There is a significant correlation between smoking and a grade of TCC $(P<0.05$; Table 3$)$. However, the present study shows no relation in the aspect of a grade of TCC and age factor though maximum number of Ca bladder was found to be in the age group of 61-70 years (Table 4).

Table 3. Impact of Smoking on Tumor Grades in TCC Cases.

\begin{tabular}{l|llll|} 
& & $\begin{array}{l}\text { Grade } \\
\text { Low grade }\end{array}$ & High grade & Total \\
\hline Smoking & No & 7 & 4 & 11 \\
& Yes & 9 & 31 & 40 \\
\hline \multirow{2}{*}{ Total } & & 16 & 35 & 51 \\
\hline
\end{tabular}

Table 4. Impact of Age on Tumor Grades in TCC Cases.

\begin{tabular}{|lcccc|} 
& & $\begin{array}{c}\text { Grade } \\
\text { Low grade }\end{array}$ & High grade & Total \\
\hline Age group & $<60$ years & 8 & 15 & 23 \\
\hline & $>60$ years & 8 & 20 & 28 \\
\hline Total & & 16 & 35 & 51 \\
\hline
\end{tabular}

\section{DISCUSSION}

Urinary bladder cancer is commonly seen in males than in females ( $M: F=3: 1)^{7,8}$ The present study also shows a similar distribution pattern $(\mathrm{M}: \mathrm{F}=3.66: 1)$. Furthermore, studies done in Malaysia and India revealed higher M:F ratio of 9.4:1 and 8.6:1 respectively which shows male preponderance. This shows that as similar to other part of the world, in Nepal also, incidence of Ca bladder is high in male than in female. The reason for higher incidence in males could be attributed to environmental, dietary exposure, anatomical difference, urinary habits and hormonal factors whereas, less incidence of bladder cancer in females could be due to less exposure of females to individual carcinogen and less smoking. ${ }^{2,9-11}$

The most common clinical manifestation was found to be a painless intermittent gross or microscopic hematuria and some patients with diffuse carcinoma in situ (CIS) can be presented with irritative voiding symptoms., ${ }^{4,9}$ In the present study, hematuria was found to be the most common clinical feature (51 out of 56) which is co existing with one or more irritative voiding symptoms. In support to the present finding, a study done in India and Pakistan has shown that $97 \%, 81.4 \%, 88.7 \%$ of the patients were having hematuria as presenting symptoms. ${ }^{8,9,12}$

In present study $78.6 \%$ patients have history of smoking, of which 38 have history of smoking for last 30 years. Among smokers with bladder cancer, 39 were male and 5 were female. The present result is comparable to the study done in India and Pakistan where the patients who were smokers having bladder cancer was $74 \%$ and $65 \%$ in males and $22 \%$ and none in females. ${ }^{8,12}$

The present study shows no direct relation between age group and $\mathrm{Ca}$ bladder but incidence increases with age. This finding is also supported by other studies. ${ }^{2,8,9,13}$ Study done in India Malaysia and Pakistan show an average age distribution of 60,65 and 58 years old respectively. $2,8,9,13$ Further, the present study has shown that low grade TCC was found in equal distribution in age $<60$ years and $>60$ years. This is in contrast to the belief that cancer in younger age group is more aggressive and younger individual present more frequently with low grade TCC. ${ }^{13}$ The current study also has revealed that there is high number of high grade TCC in patients of age above 60 years. The reason could be the smoking habit induced mutation that precipitates a bladder cancer rather than a genetic alteration. ${ }^{13}$

Smoking is already an established etiological factor of urinary bladder cancer. ${ }^{1,4}$ Tobacco increases the relative risk of developing bladder cancer by 4 fold than non smoker. ${ }^{8,14-16}$ Though, a specific chemical carcinogen responsible for bladder cancer in cigarette has not been identified, 4-aminobiphenyl and beta-napthylamyne are suggested to be the precipitating factors as the concentration of those compounds is high in the urine of smokers. ${ }^{1,17}$ Further, it is found that former smoker have lower incidence of bladder cancer than active smoker. ${ }^{13}$ The incidence of bladder cancer is also linked to p53 mutation as a study has shown that there is increase in p53 mutation in urothelial cells of smokers than non smoker. ${ }^{13}$

In present study significant impact of smoking has been found as a major risk factor for high grade TCC in which out of 35 cases of the bladder cancer with history of smoking, 31 were found to have high grade TCC, which is similar to the result of study carried out by Ray et al. in which $72 \%$ of the patients with bladder carcinoma were smokers in developing of high grade TCC. ${ }^{13}$

\section{CONCLUSION}

In conclusion, TCC is the most common histological variety of bladder cancer in Nepal accounting more than $90 \%$ of cases. The incidence of bladder carcinoma is 4 fold higher in male population and painless hematuria is the most common initial presentation. Interestingly, smoking is found to be one of the major risk factor developing of bladder carcinoma. Nevertheless, a large population based study is required for the definite conclusion. In addition, awareness among the smokers is required and also treating physician should not neglect the symptom of hematuria to prevent progression of disease to advance stage especially among smoker groups.

\section{CONTRIBUTION}

HNJ has conceptualized and designed this study whereas, AK and BS have contributed in assisting HNJ during the study period. RM has performed histopathology. RMK has helped in statistical analysis. Similarly, RS involved in result interpretation and discussion writing. IJdJ and RKM guided throughout the study period and helped in reviewing the manuscript. 


\section{REFERENCES}

1. Messing EM. Urothelial tumours of the bladder. In: Wein AJ, Kavoussi LR, Novick AC, Partin AW, Peters CA (editors). Campbell-Walsh Urology. 9th(3). Philadelphia: Saunders Elsevier 2007: pp.2407-2446.

2. Christopher Ho Chee Kong, Praveen Singam, Goh Eng Hong, Lee Boon Cheok, Muhammad Azrif, Azmi Mohd Tamil et.al (2010). Clinicopathological features of bladder tumours in a single institution in Malaysia. Asian Pasific J cancer Prev. 2010; 11: 149-152.

3. Jemal A, Siegel R, Ward E, Hao Y, Xu J, Thun MJ (2009). Cancer statistics. CA Cancer J Clin. 2009 ; 59: 529-533.

4. Kontey BR, Carroll PR. Urothelial Carcinoma: Cancers of the Bladder, Ureter and Renal Pelvis. In: Tanago EA. Mc Aninch JW (editors). Smith's General Urology. 17thed. New York: Mc Graw- Hill Companies; 2008. pp. 308-327.

5. Thompson I, Fair W. Occupational and environmental factors in bladder cancer. In: Chisolm GD, Fair WR editors: Scientific foundations of Urology. 2nd ed. Heinman Medical books; 1990.

6. Rabbani F, Cordon-Cardo C. Mutation of cell cycle regulators and their impact on superficial bladder cancer. Urol Clin North Am. 2000; 27 : 83-102. [PUBMED].

7. Jemal A, Murray T, Ward E, Samuels A, Tiwari RC, Ghafoor A, et al. Cancer statistics, 2005. CA Cancer J Clin. 2005; 55: 10-30.

8. Rafique $\mathrm{M}$ and Javed A. A . clinico-pathological features of bladder carcinoma: Experience from a tertiary care hospital of Pakistan. Int. Urol. Nephrol. 2006;38: 247-250.

9. Gupta P, Jain M, Kapoor R, Muruganandham K, Srivastava A, Mandhani A. Impact of age and gender on the clinicopathological characteristics of bladder cancer. Indian J Urol. 2009;25: 207-210.
10. Hartge P, Harvey EB, Linehan WM, et al (1990). Unexplained excess risk of bladder cancer in men. J Nat/ Cancer Inst. 1990; 82: 1636-40.

11. Horn EP, Tucker Ma, Lambert G (1995). A study of gender based cytochrome $\mathrm{P} 4501 \mathrm{~A} 2$ variability: A possible mechanism for the male excess of bladder cancer. Cancer Epidemiol Biomarkers Prev. $1995 ; 4$ : 529-33.

12. Rafique M. Clinico-pathological features of bladder carcinoma in women in Pakistan and smokeless tobacco as a possible risk factor. World Journal of Surgical Oncology. 2005; 3(53): 7819-3-53.

13. Sasco AJ, Secretan MB, Straif K. Tobacco smoking and cancer: a brief review of recent epidemiologicevidence. Lung cancer. 2004;45 (suppl 2): S3-S9

14. Ray D, Mondal R, Acharya S, De S, Mondal S. A retrospective study of bladder cancer and the impact of age, sex and smoking habits related clinicopathological correlations in tribal population of Bankura, WB, India. IOSR-JDMS. 2013; 10(4): 29-32.

15. Sen Gupta N, Siddiqui E, Mumtaz FH. Cancer of bladder. J R Soc Health 2004; 124: 228-229.

16. Burch RD, Rohan TE, Howe CR, Risch HA, Hill GB, Steele R. et al. Risk of bladder cancer by source and type of tobacco exposure. Int J Cancer 1989; 44: 622-628.

17. Carroll PR: Urothelial carcinoma: Cancers of bladder.ureter and renal pelvis. In eds Smith General Urology .15th edition. edited by "Tanagho EA, McAninch JW."USA: McGraw Hill publishers; 2000.pg 355-77. 